\title{
Kestabilan Titik Ekuilibrium Endemik Pada Model SIS Transmisi Human Papillomavirus (HPV) Dengan Populasi Berbeda
}

\author{
Irma Suryani ${ }^{1, \text { a) }}$, Wartono ${ }^{2, \text { b) }}$, Suryadi Harto. $\mathrm{P}^{3}$ \\ 1,2,3 Program Studi Matematika Fakultas Sains \& Teknologi UIN Sultan Syarif Kasim Riau \\ a)email:irma.suryani@uin-suska.ac.id \\ b)email:wartono@uin-suska.ac.id \\ c)email: suryadi220397@gmail.com
}

\begin{abstract}
Abstrak
Paper ini akan membahas model matematika Human Papillomavirus (HPV) pada model SIS dengan populasi berbeda. Pada Model SIS terdiri dari dua kompartemen, yaitu kompartemen rentan (Susceptible) dan kompartemen yang terinfeksi (Infected) dengan sub populasi perempuan $(X)$ dan sub populasi laki-laki $(Y)$. Titik ekuilibrium endemik pada model SIS ini didapat dengan melakukan manipulasi aljabar terhadap asumsi-asumsi pada model SIS Human Papillomavirus (HPV). Kemudian, kestabilan endemik diuji menggunakan matriks Jacobian dengan syarat $R_{0}$ terpenuhi dinyatakan stabil asimtotik dapat. Simulasi numerik model SIS Human Papillomavirus (HPV) diperoleh hasil kestabilan titik ekuilibrium endemik itu stabil asimtotik jika $R_{0}>1$. Hasil yang diperoleh menjelaskan bahwa subpopulasi terinfeksi akan memungkinkan menginfeksi atau menularkan virus kembali kepada sub populasi rentan. Artinya virus masih ada dalam populasi

Kata Kunci : Matriks Jacobian, model SIS, simulasi numerik, stabil asimtotik, titik ekuilibrium endemik.
\end{abstract}

\begin{abstract}
This paper will discuss a mathematical model about the stability of endemic equilibrium points on Human Papillomavirus (HPV) in SIS models with different populations. SIS Model consists of two compartments, the susceptible compartment and the infected compartment with a population that is female subpopulation $(\mathrm{X})$ and male subpopulation $(\mathrm{Y})$. Endemic equilibrium point in this SIS model is determined with algebraic manipulation of the assumptions on the SIS Human Papillomavirus (HPV) model. Then, endemic stability can be tested using the Jacobian matrix with the condition that $R_{0}$ is met so stated asymptotically stable. Numerical simulation of SIS Human Papillomavirus (HPV) model was analyzed by with the results for the stability of the endemic equilibrium point asymptotically stable if $\mathrm{R}_{0}>1$. This result explained that infected subpopulations would allow infecting or transmitting viruses to susceptible subpopulations. This means that the virus still exists in the population

Keyword : Jacobian matrix, SIS model, numerical simulation, asymptotic stable, endemic equilibrium point.
\end{abstract}




\section{Pendahuluan}

Penyakit menular seksual dikenal dengan istilah infeksi menular seksual. Penyakit menular seksual adalah penyakit atau infeksi yang umumnya ditularkan melalui hubungan seks yang tidak aman. Penyebaran bisa melalui darah, sperma, cairan vagina ataupun cairan tubuh lainnya [1]. Virus yang menyebabkan penyakit menular seksual salah satunya ialah penyakit kutil kelamin. Kutil kelamin atau kutil genital adalah penyakit menular seksual yang disebabkan oleh virus yang dikenal sebagai human papillomavirus [2].

Human papillomavirus (HPV) adalah infeksi menular seksual yang umum dan telah ditunjukkan dalam studi epidemiologis dan molekuler sebagai agen etiologi yang diperlukan untuk kanker serviks. Setidaknya tipe HPV menginfeksi daerah genital, dimana diklasifikasikan sebagai risiko tinggi, yaitu memiliki potensi onkogeni. Tipe HPV adalah tipe risiko tinggi yang paling umum, terhitung lebih dari setengah (56\%) dari semua kanker serviks. Infeksi persisten dengan tipe risiko tinggi adalah faktor risiko paling penting untuk kanker serviks. Infeksi HPV yang berlangsung lama dan tidak menentu ini berarti bahwa program skrining dapat mendeteksi dan mengobati penyakit dini dan mencegah perkembangan menjadi kanker serviks. Infeksi HPV ini memiliki variasi yang berbeda di dalam spesies bakteri dan virus atau diantara sel-sel kekebalan individu yang berbeda yang dikenal sebagai serovar atau serotipe [3].

Serotipe HPV yang berbeda telah diidentifikasi, ada serotipe risiko rendah yang bertanggung jawab untuk kerusakan anogenital jinak, dan serotipe berisiko tinggi yang dapat menyebabkan kerusakan prakanker dan kanker pada leher rahim. Studi epidemiologis pada infeksi HPV menetapkan peran virus ini sebagai penyebab utama kanker serviks. Diperkirakan bahwa infeksi HPV bertanggung jawab atas 500.000 kasus kanker serviks di seluruh dunia setiap tahun. Vaksinasi terhadap infeksi HPV merupakan cara yang efektif untuk menurunkan kejadian kanker serviks, terutama di kalangan wanita muda. Ketersediaan vaksin HPV memberikan kesempatan untuk menurunkan jumlah kasus penyakit di seluruh dunia yang disebabkan oleh HPV. Sebenarnya, 2 vaksin pencegah infeksi HPV yang telah ditemukan sangat efisien dan cocok pada wanita. Beberapa model deterministik telah dikembangkan untuk menilai dampak potensial dari vaksinasi terhadap HPV [4].

Berdasarkan uraian diatas, penulis tertarik mengulas kembali jurnal "A SIS model for Human Papilloma Virus transmission [4]" khusus endemik penyakit model SIS pada HPV dengan menambahkan simulasi numerik dari jurnal tersebut.

\section{Metode}

Studi literatur merupakan metodologi penelitian yang digunakan penulis, yaitu penulis mempelajari buku-buku atau jurnal-jurnal yang berkaitan dengan pokok permasalahan. Prosedur permasalahan ini diawali dengan populasi yang terdiri dari dua kompartemen (subpopulasi), yakni:

a. $S(t) \quad$ : Susceptible, yaitu menyatakan jumlah individu yang sehat dan rentan terhadap virus HPV

b. $\quad I(t) \quad$ : Infectible, yaitu menyatakan jumlah individu yang terinfeksi dan menularkan terhadap virus HPV

Pada penelitian ini akan mengkaji model SIS untuk transmisi HPV pada populasi heteroseksual yang aktif. Yang berarti memperhitungkan jenis kelamin perempuan (X) dan laki-laki $(Y)$ pada tiap sub populasi. Pengembangan model deterministik menggunakan (SIS) struktur rentan-terinfeksi-rentan dan vaksinasi diperhitungkan. Vaksinasi yang diperhitungkan pada jenis kelamin perempuan dan laki- 
laki masing-masing dinyatakan dalam (V) dan (W). Lebih detailnya, berikut langkah-langkah yang akan dilakukan dalam penelitian sebagai berikut:

1. Membuat asumsi yang melibatkan parameter dan variabel.

2. Membuat diagram transfer model dan menuliskan kembali Model yang ada..

3. Menentukan titik ekuilibrium dari model. Terdapat dua titik ekuilibrium yaitu titik ekuilibrium bebas penyakit dan titik ekuilibrium endemik. Dalam hal ini yang akan dibahas yaitu titik ekuilibrium endemik.

4. Menguraikan dan menganalisis kestabilan dari titik ekuilibrium endemik yang didapat dengan mencari nilai eigen dan kriteria Routh-Hurwitz dalam penentuan nilai eigen yang diperoleh.

5. Membuat simulasi numerik dengan menggunakan software Maple 13.

6. Menganalisis dan interpretasi hasil yang diperoleh.

\section{Hasil dan Diskusi}

\section{Asumsi}

Berikut diberikan diagram transfer model SIS transmisi HPV,
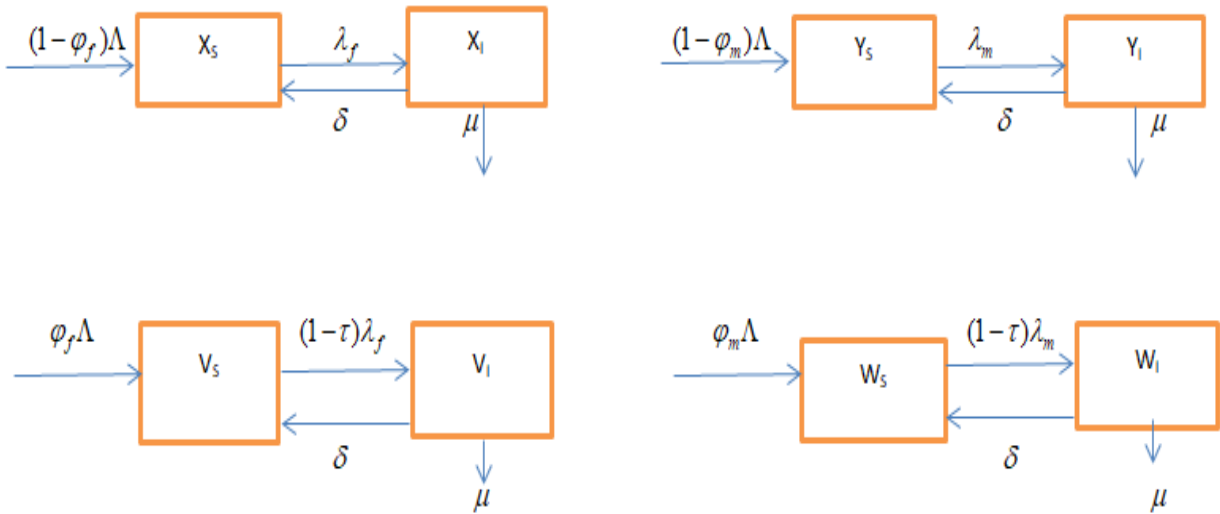

Gambar 1. Diagram transfer Model SIS Human Papillomavirus (HPV)

Diketahui kompartemen sistem non-linear model SIS transmisi Human Papillomavirus (HPV) yang merupakan model terpisah sebagai berikut:

$$
\begin{aligned}
\frac{d X_{S}}{d t} & =\left(1-\varphi_{f}\right) \Lambda-\lambda_{f} X_{S}+\delta X_{I}-\mu X_{S} \\
\frac{d X_{I}}{d t} & =\lambda_{f} X_{S}-(\delta+\mu) X_{I} \\
\frac{d Y_{S}}{d t} & =\left(1-\varphi_{m}\right) \Lambda-\lambda_{m} Y_{S}+\delta Y_{I}-\mu Y_{S} \\
\frac{d Y_{I}}{d t} & =\lambda_{m} Y_{S}-(\delta+\mu) Y_{I} \\
\frac{d V_{S}}{d t} & =\varphi_{f} \Lambda-(1-\tau) \lambda_{f} V_{S}+\delta V_{I}-\mu V_{S} \\
\frac{d V_{I}}{d t} & =(1-\tau) \lambda_{f} V_{S}-(\delta+\mu) V_{i} \\
\frac{d W_{S}}{d t} & =\varphi_{m} \Lambda-(1-\tau) \lambda_{m} W_{S}+\delta W_{I}-\mu W_{S}
\end{aligned}
$$




$$
\frac{d W_{I}}{d t}=(1-\tau) \lambda_{m} W_{S}-(\delta+\mu) W_{I}
$$

dengan,

$$
\begin{aligned}
& \lambda_{f}=\sigma_{f} \frac{\left(Y_{I}+W_{I}\right)}{N} \\
& \lambda_{m}=\sigma_{m} \frac{\left(X_{I}+V_{I}\right)}{N}
\end{aligned}
$$

Untuk mencari ukuran yang konstan dari populasi dalam model,

$$
\begin{gathered}
N=N_{f}+N_{m} \\
N_{f}=X_{S}+X_{I}+V_{S}+V_{I} \\
N_{m}=Y_{S}+Y_{i}+W_{s}+W_{I}
\end{gathered}
$$

Kemudian,

$$
\frac{d N}{d t}=2 \Lambda-\mu(N)
$$

$$
\text { Saat titik ekuilibrium } N^{*}=\frac{2 \Lambda}{\mu} \text {, hanya perlu untuk menganalisis asimtotik otonom }
$$
yang membatasi sistem dimana $N$ diganti dengan nilai ekuilibrium. Dengan Daerah Sistem yaitu,

$$
D=\left\{\left(X_{S}, X_{I}, Y_{S}, Y_{I}, V_{S}, V_{I}, W_{S}, W_{I}\right) \in R_{+}^{8}, X_{S}+X_{I}+Y_{S}+Y_{I}+V_{S}+V_{I}+W_{S}+W_{I} \leq \frac{2 \Lambda}{\mu}\right\}(3)
$$

\section{Titik Ekuilibrium}

Dengan tidak adanya vaksinasi, maka tidak ada laju vaksinasi untuk tiap jenis kelamin laki-laki dan perempuan masing-masing $\varphi_{m}$ dan $\varphi_{f}$ serta untuk setiap subpopulasi yang divaksinasi baik itu berdasarkan jenis kelamin maupun kompartement rentan/terinfeksi sama dengan nol. $\varphi_{m}=0$ dan $\varphi_{f}=0$ serta $V_{S}=V_{l}=W_{S}=W_{l}=0$. Pernyataan tersebut dapat ditulis sebagai berikut :

$$
\begin{aligned}
& \frac{d X_{S}}{d t}=\Lambda-\lambda_{f} X_{S}+\delta X_{I}-\mu X_{S} \\
& \frac{d X_{I}}{d t}=\lambda_{f} X_{S}-(\delta+\mu) X_{I} \\
& \frac{d Y_{S}}{d t}=\Lambda-\lambda_{m} Y_{S}+\delta Y_{I}-\mu Y_{S} \\
& \frac{d Y_{I}}{d t}=\lambda_{m} Y_{S}-(\delta+\mu) Y_{I} \\
& \quad \lambda_{f}=\frac{\sigma_{f} Y_{I}}{N} \text { dan } \lambda_{m}=\frac{\sigma_{m} X_{I}}{N} .
\end{aligned}
$$




\section{Titik Ekuilibrium Endemik}

Didapat titik ekuilibrium endemik:

$$
\begin{aligned}
& P_{1}=\left(X_{S}{ }^{* *}, X_{I}^{* *}, Y_{S}^{* *}, Y_{I}^{* *}\right)= \\
& \left(\frac{N\left(N \mu(\delta+\mu)^{2}+\Lambda \sigma_{m}(\delta+\mu)\right)}{\sigma_{m}\left(\Lambda \sigma_{f}+N \delta \mu+N \mu^{2}\right)}, \frac{\Lambda^{2} \sigma_{f} \sigma_{m}-N^{2} \mu^{2}(\delta+\mu)^{2}}{\mu \sigma_{m}\left(N \delta \mu+\Lambda \sigma_{f}+N \mu^{2}\right)}, \frac{N\left(N \mu(\delta+\mu)^{2}+\Lambda \sigma_{f}(\delta+\mu)\right)}{\sigma_{f}\left(N \delta \mu+\Lambda \sigma_{m}+N \mu^{2}\right)}, \frac{\Lambda^{2} \sigma_{m} \sigma_{f}-N^{2} \mu^{2}(\delta+\mu)^{2}}{\mu \sigma_{f}\left(N \delta \mu+\sigma_{m} \Lambda+N \mu^{2}\right)}\right)
\end{aligned}
$$

\section{Bilangan Reproduksi Dasar $\left(R_{0}\right)$}

Indikator utama dalam mengontrol keendemikan suatu penyakit adalah dengan rasio reproduksi dasar $\left(R_{0}\right)$. Suatu keadaan dinyatakan stabil menuju endemik apabila $R_{0}>1$, sedangkan stabil pada keadaan yang bebas penyakit apabila $R_{0}<1$, dalam hal ini setiap penderita hanya dapat menyebarkan penyakit kepada rata-rata kurang dari satu penderita baru, sehingga pada akhirnya penyakit akan hilang. Dengan kata lain jika $R_{0}<1$ maka penyakit tidak akan menyerang populasi. Sedangkan, apabila $R_{0}>1$ maka setiap penderita dapat menyebarkan penyakit kepada rata-rata lebih dari satu penderita baru, sehingga pada akhirnya akan terjadi endemis penyakit. Dengan kata lain apabila $R_{0}>1$ maka sangat mungkin penyakit untuk menyebar. Next Generation Matrice (NGM) [5] digunakan untuk menghitung bilangan reproduksi dasar $\left(R_{0}\right)$. Didefinisikan dengan dua subpopulasi yang sesuai untuk subpopulasi terinfeksi dan sub populasi yang rentan yaitu:

$$
\dot{x}=\left(\dot{X}_{I}, \dot{X}_{S}, \dot{Y}_{I}, \dot{Y}_{S}\right)^{T}(0,0,0,0)^{T}
$$

Menggunakan metode Next Generation Matrice, diperoleh:

$$
R_{0}=\sqrt{R_{0, f} R_{0, m}}
$$

dengan,

$$
R_{0, f}=\frac{\sigma_{f}}{2(\delta+\mu)} \text { dan } R_{0, m}=\frac{\sigma_{m}}{2(\delta+\mu)} .
$$

\section{Kestabilan Titik Ekuilibrium Endemik}

Analisis Kestabilan ditentukan berdasarkan nilai eigen dari matriks Jacobian [6],[7] yang diperoleh melalui metode linearisasi. Matriks Jacobian dari Persamaan (4) sebagai berikut:

$$
J(P)=\left|\frac{\partial F_{1}}{\partial X_{I}} \frac{\partial F_{1}}{\partial Y_{I}} \frac{\partial F_{2}}{\partial X_{I}} \frac{\partial F_{2}}{\partial Y_{I}} \frac{\partial F_{1}}{\partial X_{S}} \frac{\partial F_{1}}{\partial Y_{S}} \frac{\partial F_{2}}{\partial X_{S}} \frac{\partial F_{2}}{\partial Y_{S}} \frac{\partial F_{3}}{\partial X_{I}} \frac{\partial F_{3}}{\partial Y_{I}} \frac{\partial F_{4}}{\partial X_{I}} \frac{\partial F_{4}}{\partial Y_{I}} \frac{\partial F_{3}}{\partial X_{S}} \frac{\partial F_{3}}{\partial Y_{S}} \frac{\partial F_{4}}{\partial X_{S}} \frac{\partial F_{4}}{\partial Y_{S}}\right|
$$




$$
\begin{gathered}
J(P)=\mid-(\delta+\mu) \frac{\sigma_{f}}{N} X_{S}^{* *} \frac{\sigma_{m}}{N} Y_{S}^{* *}-(\delta+\mu) \frac{\sigma_{f}}{N} Y_{I}^{* *} \quad 00 \quad \frac{\sigma_{m}}{N} X_{I}^{* *} \delta-\frac{\sigma_{f}}{N} X_{S}^{* *}-\frac{\sigma_{m}}{N} Y_{S}^{* *} \delta \\
-\frac{\sigma_{f}}{N} Y_{I}^{* *}-\mu 00-\frac{\sigma_{m}}{N} X_{I}^{* *}-\mu \mid
\end{gathered}
$$

Lebih lanjut, akan dibahas kestabilan titik ekuilibrium endemik penyakit sebagai berikut.

Teorema 1 Jika $R_{0}>1$ maka titik ekuilibrium endemik

$$
\begin{gathered}
P_{1}=\left(X_{S}^{* *}, X_{I}^{* *}, Y_{S}^{* *}, Y_{I}^{* *}\right) \\
=\left(\frac{N\left[N \mu(\delta+\mu)^{2}+\Lambda \sigma_{m}(\delta+\mu)\right]}{\sigma_{m}\left(\Lambda \sigma_{f}+N \delta \mu+N \mu^{2}\right)}, \frac{\Lambda^{2} \sigma_{f} \sigma_{m}-N^{2} \mu^{2}(\delta+\mu)^{2}}{\mu \sigma_{m}\left(N \delta \mu+\Lambda \sigma_{f}+N \mu^{2}\right)}, \frac{N\left[N \mu(\delta+\mu)^{2}+\Lambda \sigma_{f}(\delta+\mu)\right]}{\sigma_{f}\left(N \delta \mu+\Lambda \sigma_{m}+N \mu^{2}\right)}, \frac{\Lambda^{2} \sigma_{m} \sigma_{f}-N^{2} \mu^{2}(\delta+\mu)^{2}}{\mu \sigma_{f}\left(N \delta \mu+\sigma_{m} \Lambda+N \mu^{2}\right)}\right)
\end{gathered}
$$

stabil asimtotik.

\section{Bukti:}

karena titik ekuilibrium endemik

$$
\begin{gathered}
P_{1}=\left(X_{S}^{* *}, X_{I}^{* *}, Y_{S}^{* *}, Y_{I}^{* *}\right) \\
=\left(\frac{N^{2} \mu(\delta+\mu)^{2}+\Lambda N \sigma_{m}(\delta+\mu)}{\sigma_{m}\left(\Lambda \sigma_{f}+N \delta \mu+N \mu^{2}\right)}, \frac{\Lambda^{2} \sigma_{f} \sigma_{m}-N^{2} \mu^{2}(\delta+\mu)^{2}}{\mu \sigma_{m}\left(N \delta \mu+\Lambda \sigma_{f}+N \mu^{2}\right)}, \frac{N^{2} \mu(\delta+\mu)^{2}+\Lambda N \sigma_{f}(\delta+\mu)}{\sigma_{f}\left(N \delta \mu+\Lambda \sigma_{m}+N \mu^{2}\right)}, \frac{\Lambda^{2} \sigma_{m} \sigma_{f}-N^{2} \mu^{2}(\delta+\mu)^{2}}{\mu \sigma_{f}\left(N \delta \mu+\sigma_{m} \Lambda+N \mu^{2}\right)}\right)
\end{gathered}
$$

Sehingga matriks (8) menjadi

$$
\begin{aligned}
& \mid-(\delta+\mu) \frac{\sigma_{f}}{N}\left(\frac{N^{2} \mu(\delta+\mu)^{2}+\Lambda N \sigma_{m}(\delta+\mu)}{\sigma_{m}\left(\Lambda \sigma_{f}+N \delta \mu+N \mu^{2}\right)}\right) \frac{\sigma_{f}}{N}\left(\frac{\Lambda^{2} \sigma_{m} \sigma_{f}-N^{2} \mu^{2}(\delta+\mu)^{2}}{\mu \sigma_{f}\left(N \delta \mu+\sigma_{m} \Lambda+N \mu^{2}\right)}\right) 0 \frac{\sigma_{m}}{N}\left(\frac{N^{2} \mu(\delta+\mu)^{2}+\Lambda N \sigma_{f}(\delta+\mu)}{\sigma_{f}\left(N \delta \mu+\Lambda \sigma_{m}+N \mu^{2}\right)}\right) \\
& -(\delta+\mu) 0 \frac{\sigma_{m}}{N}\left(\frac{\Lambda^{2} \sigma_{f} \sigma_{m}-N^{2} \mu^{2}(\delta+\mu)^{2}}{\mu \sigma_{m}\left(N \delta \mu+\Lambda \sigma_{f}+N \mu^{2}\right)}\right) \delta-\frac{\sigma_{f}}{N}\left(\frac{N^{2} \mu(\delta+\mu)^{2}+\Lambda N \sigma_{m}(\delta+\mu)}{\sigma_{m}\left(\Lambda \sigma_{f}+N \delta \mu+N \mu^{2}\right)}\right) \\
& -\frac{\sigma_{f}}{N}\left(\frac{\Lambda^{2} \sigma_{m} \sigma_{f}-N^{2} \mu^{2}(\delta+\mu)^{2}}{\mu \sigma_{f}\left(N \delta \mu+\sigma_{m} \Lambda+N \mu^{2}\right)}\right)-\mu 0-\frac{\sigma_{m}}{N}\left(\frac{N^{2} \mu(\delta+\mu)^{2}+\Lambda N \sigma_{f}(\delta+\mu)}{\sigma_{f}\left(N \delta \mu+\Lambda \sigma_{m}+N \mu^{2}\right)}\right) \delta 0 \\
& -\frac{\sigma_{m}}{N}\left(\frac{\Lambda^{2} \sigma_{f} \sigma_{m}-N^{2} \mu^{2}(\delta+\mu)^{2}}{\mu \sigma_{m}\left(N \delta \mu+\Lambda \sigma_{f}+N \mu^{2}\right)}\right)-\mu \mid
\end{aligned}
$$

Untuk mencari nilai eigen dari matriks $J\left(P_{1}\right)$ yang berukuran $4 \times 4$ di bentuk persamaan karakteristik dari determinan yaitu:

$$
\operatorname{det}\left[\left(P_{1}\right)-\lambda I\right]
$$

Lebih lanjut, nilai eigen $\lambda_{1}, \lambda_{2}, \lambda_{3}$, dan $\lambda_{4}$ diperoleh dengan menggunakan kriteria Routh-Hurwitz [3]. Hasil yang didapat nilai eigen $\lambda_{1}, \lambda_{2}, \lambda_{3}$, dan $\lambda_{4}$ bernilai negatif jika $R_{0}>1$. Dan terlihat jelas bahwa 4 nilai eigen tersebut memiliki nilai negatif, maka titik kesetimbangan $P_{1}$ stabil asimtotik.

\section{Simulasi}

Simulasi dilakukan untuk menggambarkan secara jelas mengenai kestabilan titik ekuilibrium endemik model SIS transmisi Human papillomavirus (HPV) dengan populasi berbeda dan nilai awal setiap subpopulasi.

Pada bagian ini akan dilakukan simulasi pada titik ekuilibrium endemik dengan menggunakan Software Maple 13 seperti pada tabel 1 berikut. 
Tabel 1 Nilai Parameter untuk endemik Human papillomavirus (HPV)

\begin{tabular}{ccc}
\hline Parameter & Nilai & Sumber \\
\hline$\mu$ & 0.0021 & (Suryani, 2019) \\
$\delta$ & 0.01 & (Suryani, 2019) \\
$\lambda_{m}$ & 0.001 & (Suryani, 2019) \\
$\lambda_{f}$ & 0.005 & (Suryani, 2019) \\
$\Lambda$ & 0.05 & (Suryani, 2019) \\
$\sigma$ & 0.025 & Asumsi \\
$\sigma_{m}$ & 1000 & Asumsi \\
$\sigma_{f}$ & 1000 & Asumsi \\
\hline
\end{tabular}

Sumber: Suryani,2019 [11]

Hasil simulasi dari populasi endemik Human Papillomavirus (HPV) dapat dilihat sebagai berikut:

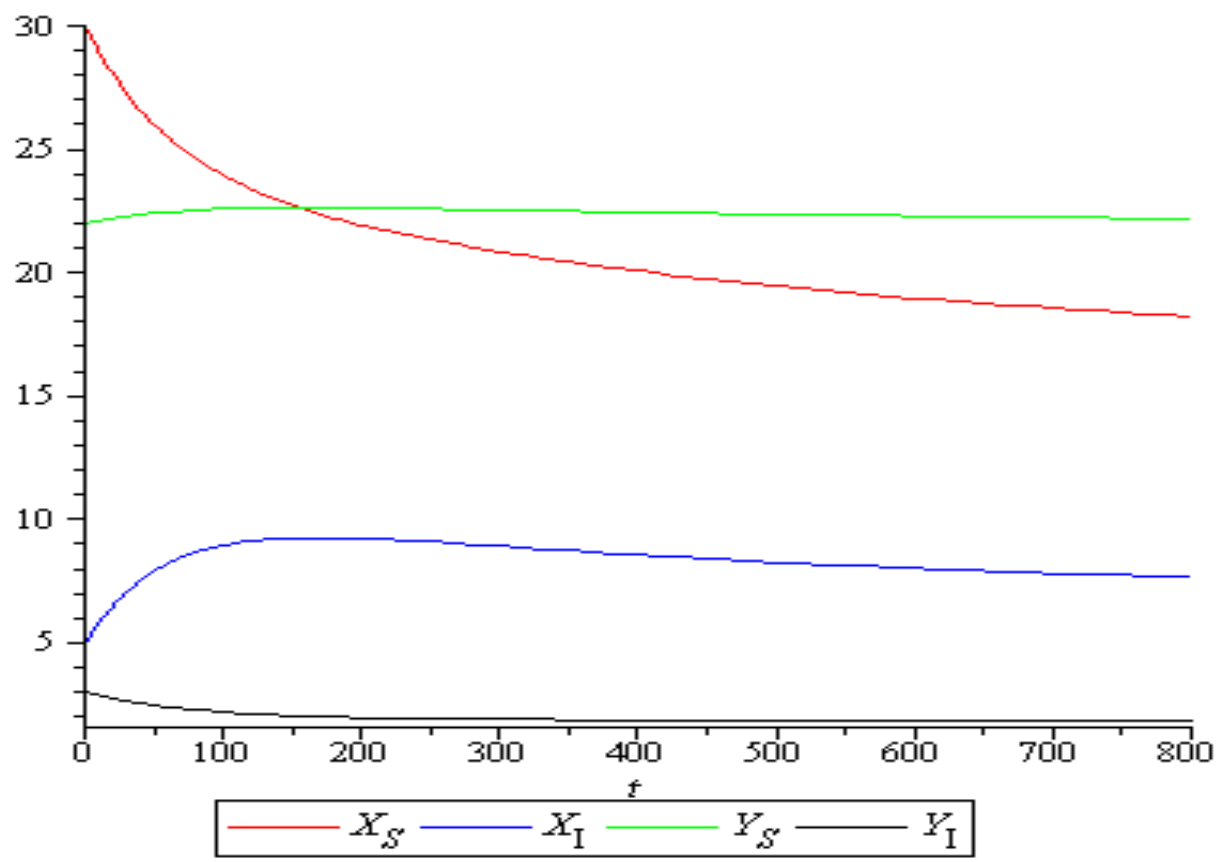

Gambar 2. Simulasi Titik Ekuilibrium Endemik Human Papillomavirus (HPV)

Dari Gambar 2 dapat dilihat bahwa Sub Populasi rentan perempuan menurun dan sub populasi terinfeksi perempuan naik dan turun secara signifikan. Sedangkan sub populasi rentan laki-laki naik yang tidak terlalu signifikan kemudian stabil dan sub populasi terinfeksi laki-laki turun namun tidak habis dalam populasi. Ini menunjukkan bahwa ada potensi sub populasi laki-laki dan sub populasi perempuan akan kembali menularkan virus HPV di dalam populasi. Artinya, virus HPV tidak akan hilang di dalam populasi dan sub populasi rentan akan kembali terinfeksi virus HPV. 


\section{Kesimpulan}

Berdasarkan pembahasan diperoleh:

1. Kestabilan pada titik ekuilibrium endemik pada model adalah stabil asimtotik, artinya untuk jangka waktu yang lama sub populasi akan berkurang dan bertambah sehingga pada akhirnya menjadi konstan pada waktu tertentu.

2. Simulasi numerik pada Gambar 1 menjelaskan bahwa subpopulasi terinfeksi akan menginfeksi atau menularkan virus HPV pada sub populasi rentan. Dengan demikian, virus HPV masih ada di dalam populasi.

\section{Referensi}

[1] Nurhalimah, N., dkk, "Analisis Kestabilan Model Matematika SIA (Susceptible, Infected, AIDS Cases) untuk Penyakit AIDS", Kubik: Jurnal Publikasi IImiah Matematika Vol. 3 No.1, pp. 83-87, 2018

[2] Jevuska. "Penyakit Menular Seksual - Pengertian dan Sejenisnya". https://www.jevuska.com/category/artikel-kedokteran/kulit (di akses tanggal 5 Desember 2019)

[3] Barnabas, R.V. dkk. "Epidemiology of HPV 16 and Cervical Cancer in Finland and the Potential Impact of Vaccination: Mathematical Modelling Analyses". Journal of Plos Medicine. 2006

[4] Ribassin, L dan Majed. "A SIS Model for Human Papillomavirus Transmission". Version 1. Villejuif: Journal Institut de Cancérologie Gustave Roussy. 2010

[5] Driessche \& Watmough. Reproduction Number and Subthreshold Endemic Equilibria for Compartmental Model of Disease Transmission. Mathematical Biosciences 18. Hal. 2. 2002

[6] Hale, J. K. “Ordinary Differential Equations". Georgia: Dover Publications. 2009

[7] Perko, L. "Differential Equations Dynamika System". New York: Springer-Verlag. 1991

[8] Grantmacher, F.H., Applications Of The Theory Matrices, Intersciences Publisher, New York, 1959

[9] Suryani, I dan Asandi, A. "Kestabilan Global Titik Ekuilibrium Bebas Penyakit Pada Model SIS Transmisi Human Papillomavirus (HPV) dengan Populasi Berbeda". Jurnal Sains Matematika dan Statistik. 2019 